\title{
DIGITAL CAPACITY OF RUSSIAN TOURIST TERRITORIES
}

\author{
Anna MIKHAYLOVA \\ Immanuel Kant Baltic Federal University, Institute of Regional and Geopolitical Studies, \\ Center for Baltic Studies, Gaidara 6, 236029, Kaliningrad, Russian Federation, e-mail: tikhonova.1989@mail.ru \\ Julia GONCHAROVA \\ Immanuel Kant Baltic Federal University, Institute of Regional and Geopolitical Studies, \\ Center for Baltic Studies, Gaidara 6, 236029, Kaliningrad, Russian Federation, e-mail: j.spirina@ mail.ru
}

\section{Angelina PLOTNIKOVA}

Immanuel Kant Baltic Federal University, Institute of Regional and Geopolitical Studies, Innovation Geography Laboratory, Gaidara 6, 236029, Kaliningrad, Russian Federation, e-mail: a.plotnikova.1416@gmail.com

\section{Andrey MIKHAYLOV*}

Institute of Geography of the Russian Academy of Sciences, Laboratory of Geopolitical Studies, Staromonetny pereulok 9, 119017, Moscow, Russian Federation; Immanuel Kant Baltic Federal University, Institute of Regional and Geopolitical Studies Studies, Innovation Geography Laboratory, Gaidara 6, 236029, Kaliningrad, Russian Federation, e-mail: mikhailov.andrey@ yahoo.com

Citation: Mikhaylova, A., Goncharova, J., Plotnikova, A., \& Mikhaylov, A. (2021). DIGITAL CAPACITY OF RUSSIAN TOURIST TERRITORIES. GeoJournal of Tourism and Geosites, 35(2), 322-331. https://doi.org/10.30892/gtg.35209-655

\begin{abstract}
Digitalization has affected the economies and the everyday life of the population all around the globe. Industries are going digital with the Industry 4.0 mode changing the conventional practices of doing business. People spend a significant amount of time online shifting their daily routines to electronic format. The wide dissemination and adoption of ICTs place mutual expectations from the population to have competence in using modern digital technologies and from firms and public institutions to provide their services online. Not surprisingly there is a strong digital divide between territories in their digital capacity - the ability of a territory to generate digital content. This study is aimed at evaluating the digital capacity of cities and municipalities in Russia by measuring their digital footprint in the tourism industry. Tourism is found to be an information intensive economy sector with a large volume of consumer-generated content making it ideal for measuring the digital capacity of territories. The research design is based on geotagged hashtags sourced from Instagram - one of the most popular social networks worldwide. The geographical scope of research covers 205 cities in 10 regions of Russia - Arkhangelsk region (14 municipalities), the Republic of Crimea and Sevastopol (19 municipalities), Kaliningrad region (28 municipalities), Krasnodar region (26 municipalities), Leningrad region (69 municipalities), Murmansk region (16 municipalities), and Rostov region (23 municipalities). All of the regions are located in the European part of the country but differ in environmental, socio-economic, and geopolitical parameters. In order to focus on the tourism sector, the dataset on tourist accommodation establishments and bed places is collected in addition to population statistics. The analyzed data is mapped, and a series of figures present the re search findings. The research results suggest that consumer-generated content with place-related hashtags in Instagram is applicable for tracking the tourism sector development and the tourism-related digital capacity of a territory. However, a number of limitations are identified in using user-generated digital content in social media. This includes overrepresentation of large cities over smaller settlements despite not being the direct location of reference; 'noisy data' featuring additional meaningless information due to ambiguous hashtags; an increasing volume of commercial posts from bloggers, self-employed, and business.
\end{abstract}

Key words: digitalization, digital capacity, tourism industry, digital footprint, technology acceptance, digital routine, Russia

\section{INTRODUCTION}

Since the $21^{\text {st }}$ century, worldwide Internet usage has shown exponential growth - from $6.5 \%$ of the population in 2000 to $51.0 \%$ individuals in 2019 being subscribed to the Internet (World Bank, 2021). Other estimates suggest that the average worldwide growth of users between 2000-2021 was even higher, reaching 1,300\% due to an immence growth rates in Africa and the Middle East (Miniwatts Marketing Group, 2021). According to the U.S. Central intelligence agency (CIA), there are 4.1 billion Internet users around the globe with the following top ten countries by the number of users (in millions): China 730.7, India - 374.3, the United States - 246.8, Brazil - 122.8, Japan - 116.6, Russia - 108.8, Mexico - 73.3, Germany 72.3, Indonesia - 65.5, and the United Kingdom - 61. Impressive growth and geographical coverage also observed for mobile Internet. The 2019 data of the GSM association suggests that $47 \%$ of the global population (over 3.5 billion people) are connected to mobile internet, while the share of the population living within the areas covered by mobile broadband networks continues to increase. International Telecommunication Union report of 2020 (International Telecommunication 
Union, 2020) reflects that $93.2 \%$ of the world population is covered by a mobile broadband network, including $85 \%$ are estimated to have access to a fast-speed $4 \mathrm{G}$ network as of 2020 . These data imply a widespread integration of digital technologies and the virtual realm in the everyday life of the population around the globe.

Due to the availability of required infrastructure, affordability of Internet subscriptions, and relative consumer readiness for using online services, there is a trend of moving digital by various businesses and public services - retail, insurance services, entertainment industry, etc. People are increasingly switching their daily routines to electronic format, e.g. online shopping, electronic banking, distant learning, telemedicine. The vast dissemination and adoption of digital technologies by society has also facilitated the digitalization of state services being delivered to citizens. In some countries, the e-government format has become dominant over the past few years. For example, in Estonia, 99\% of public services are available online, and people tend to prefer the electronic format overall $-95 \%$ of people submit their tax returns online, $99.6 \%$ of bank transactions are done via the Internet (Mikhaylova, 2019; Tupay, 2020). The digital era of governance is not only making governmental institutions and businesses increasingly reliant on digital technologies but placing the expectations on citizens to be online and act digitally (Schou and Hjelholt, 2018). This digital transformation means that many activities of everyday life are being transferred to the Internet and mobile technologies, thus, framing the new standards and behaviors (Brodovskaya and Huang, 2019).

The new notions of a 'digital nation', 'digital society', 'digital population', 'digital citizen' are being extensively discussed and the prospects of upcoming changes are being debated. Alongside the increasing penetration of Information and Communication Technologies (ICT) and digital online platforms into the public domain, digitalization is expected to increase its impact on the elements of smart cities (e.g. the public transport ticketing and schedule, the sightseeing QR codes, etc.) and the development of regional societies (Bouzguenda et al., 2019; Hu et al., 2020). The digital revolution impacts the economy structure, which is being re-engineered and restructured towards Industry 4.0 and the fast-growing high-tech 'propulsive' industries (Kuznetsov et al., 2019; Pencarelli, 2020; Stankov and Gretzel, 2020). According to Abou-Shouk et al. (2013), one of the strongest changes are found in the service sector and tourism industry, in particular, especially considering the volume of e-tourism services rendered, such as hotel and travel ticket bookings sold via the Internet. Tourists tend to book the entire trip using personal digital devices (Happ and Horváth Ivancsóné, 2020). Digitalization changes the structure of the tourism industry challenging the firms' efficiency by intensified competition and transparent pricing (Ruiz-Gómez et al., 2018). Tourism has become an information-intensive industry with information technology driving the critical changes of consumer behavior and the distribution of travel-related information (Yeoman and McMahon-Beattie, 2006; Xiang and Gretzel, 2010).

The aim of this study is to evaluate the digital capacity of cities and municipalities in Russia by measuring their digital footprint in the tourism industry. We apply the geotagged consumer-generated content (CGC) from social media as an indication of the ability of a territory to generate digital content. Our research hypothesis suggests that the new types of digital data (big data) can act as a marker of the tourism industry development potential. The article proceeds with a literature review on the digitalization of the tourism industry with an emphasis on user-generated content and Web 2.0. The materials and methods section presents a logical framework and the steps of the research design. The research results show the data obtained, which is synthesized in a series of regional-level maps. The paper closes with a discussion and conclusions on the key findings, providing observations on the spatial patterns of the digital capacity of tourist territories in Russia.

\section{LITERATURE REVIEW}

In recent years, the two digital megatrends have considerably changed the "rules of the game" in the tourism industry (Leung et al., 2013; Munar and Jacobsen, 2014; Xiang and Gretzel, 2010). The first trend is related to the early development stage of the World Wide Web or Web 1.0, which is associated with static (non-interactive) websites and, most importantly, search engines. With the availability of websites featuring detailed information on the market offerings, the all-embracing search engines (such as Google, Yandex) and the aggregator websites that present the whole variety of competitive goods provided and services rendered (e.g. Booking, Momondo, etc.) the customer got the opportunity to compare and choose offers in the B2C format, self-plan holidays and self-manage all bookings and payments. However, soon the second trend has come to the forefront - Web 2.0 with the user-generated content (conceptualized as consumer-generated content - CGC). The social media websites present the travel-related personal experiences, opinions, and comments in a variety of different forms - social network sites (e.g. Facebook), media-sharing sites (e.g. Instagram, Flickr, YouTube), review sites (e.g. TripAdvisor, Booking.com, Trivago, Yelp, Vacatia, Google Trips) and voting sites (e.g. Digg), blogs (e.g. Travelblog, Travellerspoint) and microblogs (e.g. Twitter), social bookmarking sites (e.g., Delicious), social knowledge sharing sites (e.g. Wikitravel), and numerous virtual travel communities (Leung et al., 2013; Munar and Jacobsen, 2014; Xiang and Gretzel, 2010; Li et al., 2021). This CGC is the "media impressions created by consumers, typically informed by relevant experience, and archived or shared online for easy access by other impressionable consumers" (Blackshaw and Nazzaro, 2006). This content is generally perceived as a marketing-free view on the product and contrasts the Internet marketing that has become more sophisticated in recent years.

A review by Leung et al. (2013) suggests that researchers widely register the strategic importance of social media for tourism and hospitality competitiveness as the CGC is increasingly adopted by travelers in their decision making. Li et al. (2021) indicate that websites and mobile applications provide tourists with communication channels to share information, express opinions, and process bookings. The immense amount of data on travel experiences that are being stored on social media and supplemented with individual travel stories are becoming an increasingly dominant domain in travelers' information search and decision making (Choe et al., 2017). Xiang and Gretzel (2010) orecast that the dedicated travel websites with CGC (such as TripAdvisor, VirtualTourist, IgoUgo, and the alike) along with blogs and social networking sites are evolving into primary sources of information on tourist destinations. Given the importance of the travel data available scholars are developing new methods of capturing and processing this information. 
The digital footprints of travelers account for a large volume of semi-structured 'big data', such as photos, videos, posts, reviews, or other types of social media, that are impossible to analyze using traditional research methods (Gunter and Önder, 2021). The initial focus of researchers was drawn to text-mining, analyzing questions and answers in forums and user-provided reviews on TripAdvisor, Priceline, Hotels.com, Expedia, Booking.com, etc., posts and reposts with travel experiences, Twitter messages, whereas recent studies are increasingly focusing on the content and metadata from photos and videos (Li et al., 2018; Orsi and Geneletti, 2013; Ma et al., 2018). Back in 2014 Munar and Jacobsen (2014) have revealed a dominance of visual content in the tourism industry, which was recently verified by numerous studies (Aramendia-Muneta et al., 2021; Payntar et al., 2021). Scholars make use of georeferenced information sourced from metadata attached to CGC, typically indicating the latitudinal and longitudinal coordinates, geotags, or hashtags (Gunter and Önder, 2021).

Geotagged photos have been previously applied for tracking the tourist flows and movement patterns (Girardin et al., 2008; Önder et al., 2016; $\mathrm{Vu}$ et al., 2015), identify and rank the popularity of tourist attractions and determine tourism demand (Kadar and Gede, 2013; Gunter and Önder, 2021), draw the interdependence and quantify the role of the UNESCO World Heritage sites in regional tourism sector (Payntar et al., 2021), compare the recreational activities of locals and tourists (García -Palomares et al., 2015; Yuan and Medel, 2016), as well as build tourist guides (Jiang et al., 2013). In recent years Instagram is becoming a particularly popular data source for having a large number of users around the globe, as well as due to the system of user-defined hashtags that enable to capture and process of big data in large-scale qualitative geographical studies.

\section{MATERIALS AND METHODS}

The research design of the study is set up to test the hypothesis on the user-generated digital content acting as a marker of the tourism industry development potential. In particular, we focus on measuring the digital capacity of territories, which is defined by their ability to generate digital content. That is, does the location in question has a sufficient number of tourist attractions, their level of recreation and hospitality sector development, the attractiveness of cultural heritage and geo-sites.

Instagram is used as the primary source of data. Unlike some other competitive social media, Instagram specializes in photos and offers a user-friendly mobile application for both professionals and the general public. We have used a list of location-specific hashtags to source statistics on posts (digital footprint) and map them accordingly. For research purposes, the following hashtag form was used: \#“city name". The search was carried out in the Russian-language segment of the social network.

Table 1. Territorial coverage of research by hashtags of tourist regions of Russia (Data source: developed by the authors)

\begin{tabular}{|c|c|c|c|c|}
\hline \multirow{2}{*}{ Region name } & \multicolumn{2}{|r|}{ Urban settlements considered (cities and urban-type settlements) } & \multirow{2}{*}{$\begin{array}{l}\text { Number } \\
\text { of } \\
\text { hashtags, } \\
\text { thousand }\end{array}$} & \multirow{2}{*}{$\begin{array}{l}\text { Population size } \\
\text { in settlements of } \\
\text { the sample, } \\
\text { thousand people }\end{array}$} \\
\hline & No. & name & & \\
\hline $\begin{array}{l}\text { Arkhangelsk region } \\
\text { (including the Nenets } \\
\text { Autonomous District) }\end{array}$ & 14 & $\begin{array}{l}\text { Arkhangelsk, Severodvinsk, Kotlas, Mirny, Koryazhma, Novodvinsk, Velsk, } \\
\text { Nyandoma, Onega, Kargopol, Shenkursk, Mezen, Solvychegodsk, Naryan-Mar }\end{array}$ & 3498.6 & 802.1 \\
\hline Murmansk region & 16 & $\begin{array}{l}\text { Murmansk, Severomorsk, Apatity, Monchegorsk, Kandalaksha, Kirovsk, Olenegorsk, } \\
\text { Polyarny, Kovdor, Zapolyarny, Polyarnye Zori, Snezhnogorsk, Zaozersk, Gadzhievo, } \\
\text { Kola, Ostrovnoy }\end{array}$ & 3728.7 & 623.2 \\
\hline Leningrad region & 69 & $\begin{array}{l}33 \text { cities (Vyborg, Gatchina, Kingisepp, Tikhvin, Sosnovyy Bor, Kirishi, Luga, } \\
\text { Vsevolozhsk, Volkhov, Tosno, Priozersk, Slantsy, Lodeynoye Pole, Svetogorsk, } \\
\text { Pikalovo, Podporozh'ye, Boksitogorsk, Kirovsk, Shlissel'burg, Ivangorod, Volosovo, } \\
\text { Syas'stroy, Novaya Ladoga, Otradnoye, Sertolovo, Kamennogorsk, Kommunar, Nikol'skoye, } \\
\text { Lyuban', Primorsk, Vysotsk, Murino, Kudrovo) and } 36 \text { urban-type settlements }\end{array}$ & 5713.1 & 1260.3 \\
\hline St. Petersburg & 10 & $\begin{array}{l}\text { St. Petersburg, Kronstadt, Pushkin, Kolpino, Peterhof, Lomonosov, Zelenogorsk, } \\
\text { Krasnoe Selo, Sestroretsk, Pavlovsk }\end{array}$ & 21289.6 & 5975.2 \\
\hline Kaliningrad region & 28 & $\begin{array}{l}\text { Kaliningrad, Baltiysk, Gusev, Chernyakhovsk, Sovetsk, Guryevsk, Gvardeysk, } \\
\text { Zelenogradsk, Svetly, Neman, Svetlogorsk, Mamonovo, Bagrationovsk, Pionersky, } \\
\text { Nesterov, Polessk, Slavsk, Ozersk, Krasnoznamensk, Pravdinsk, Ladushkin, } \\
\text { Yantarny, Znamensk Primorye, Rybachy, Donskoe }\end{array}$ & 9171.7 & 788.8 \\
\hline Krasnodar region & 26 & $\begin{array}{l}\text { Krasnodar, Sochi, Novorossiysk, Armavir, Anapa, Labinsk, Yeisk, Gelendzhik, } \\
\text { Tikhoretsk, Tuapse, Slavyansk-on-Kuban, Kropotkin, Krymsk, Belorechensk, } \\
\text { Timashevsk, Temryuk, Kurganinsk, Ust-Labinsk, Gulkevichi Klyuch, Korenovsk, } \\
\text { Goryachynsk, Korenovsk, Abinsk, Novokubansk, Primorsko-Akhtarsk, Khadyzhensk }\end{array}$ & 78102.3 & 2986.7 \\
\hline Rostov region & 23 & $\begin{array}{l}\text { Rostov-on-Don, Taganrog, Volgodonsk, Mines, Novocherkassk, Azov, Kamensk- } \\
\text { Shakhtinsky, Bataysk, Novoshakhtinsk, Salsk, Donetsk, Belaya Kalitva, Gukovo, } \\
\text { Millerovo, Krasny Sulin, Morozovsk, Zernograd, Aksai, Semikarakorsk, Zverevo, } \\
\text { Konstantin Tsimlyansk, Proletarsk }\end{array}$ & 21626.6 & 2821.6 \\
\hline Republic of Crimea & 16 & $\begin{array}{l}\text { Simferopol, Belogorsk, Kerch, Evpatoria, Yalta, Feodosia, Dzhankoy, Saki, Bakhchisarai, } \\
\text { Alushta, Krasnoperekopsk, Sudak, Armyansk, Staryy Krym, Shchelkino, Alupka }\end{array}$ & 13310.8 & 975.2 \\
\hline Sevastopol & 3 & Sevastopol, Inkerman, Balaklava & 4968.3 & 482.3 \\
\hline
\end{tabular}

The geography of the study covered municipalities of two types (municipal districts and urban districts) in nine regions of the Russian Federation, of which in the north - the Arkhangelsk region (20 municipal districts and 8 urban districts) and the Murmansk region (5 municipal districts and 12 urban districts); in the northwest - the Leningrad region (17 municipal districts and 1 urban district), the Kaliningrad region (22 urban districts) and the federal city of St. Petersburg; in the south - Rostov 
region (43 municipal districts and 12 urban districts), Krasnodar region (37 municipal districts and 7 urban districts), the Republic of Crimea (14 municipal districts and 11 urban districts) and the federal city of Sevastopol. The download of the hashtag database from Instagram was carried out in 2020 in the context of 205 urban settlements that are part of these municipalities and, in most cases, are their administrative and territorial centers (Table 1). Figure 1 presents the geography of the studied areas. All of the regions are located in the European part of the country but differ in environmental, socio-economic, and geopolitical parameters. For example, Murmansk Oblast is located in the Arctic Circle, Kaliningrad Oblast is an exclave territory, and Leningrad Oblast surrounds Saint Petersburg with numerous historical heritage sites and beautiful architecture.

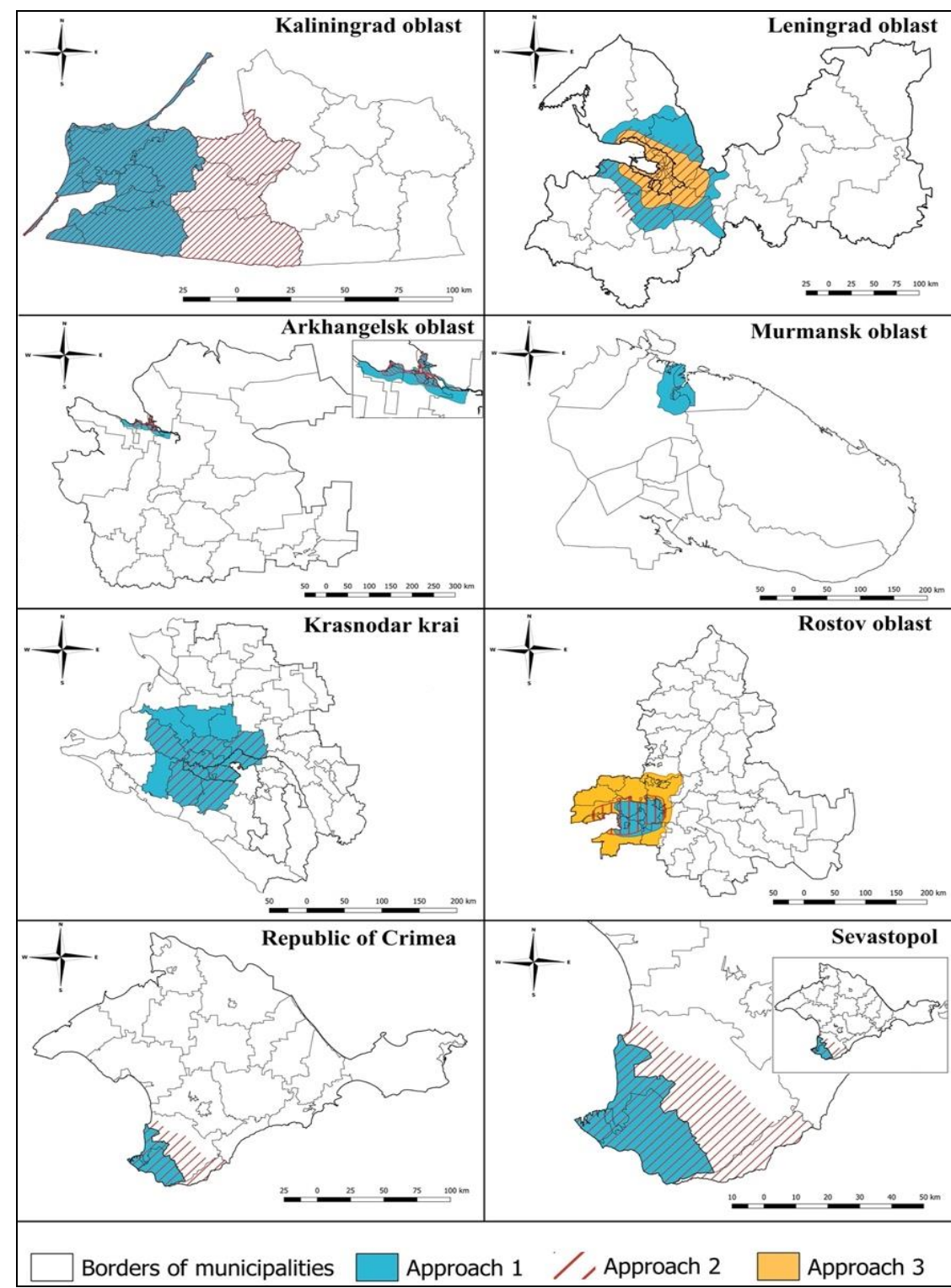

Figure 1. The location of the study area (Source: developed by the authors)

The conventional tourism industry statistics are downloaded from the Federal State Statistics Service of the Russian Federation (Rosstat, URL: https://eng.rosstat.gov.ru). The following regional level indicators are used to compare with geotagged photos from Instagram: the number of tourist accommodation establishments per 10,000 population, the number of bed places per tourist accommodation establishment. All of the data is scaled in a comparable form and unified across the eight regions under consideration. Data is presented as of 2019. An important element of the study is the delimitation of the urban agglomeration (Figure 1). In our study, we proceeded from the fact that the generation of hashtags in a social network can be influenced not only by the tourist attractiveness of territory but also by the agglomeration factor, due to a higher concentration of residents around large cities. In this regard, we have compared three dimensions: agglomeration boundaries, tourist areas, and geotags. The delimitation is done based on the structured literature review of original studies on these regions. Arkhangelsk Oblast has two major delimitation approaches: considering near urban districts and adjacent rural settlements (10 municipalities) or an expanded agglomeration to the Kholmogorskiy district and the village of Nenoksa at the north-west (16 municipalities). The Crimea Republic and Sevastopol form a single bi-polar conurbation with centers in Simferopol and Sevastopol.

Simferopol agglomeration is structured in three belts of transport accessibility (near, middle, remote) or expanded to Dzhankoy on the north and Evpatoria on the west, including the Bakhchisarai district (7-10 municipalities). Sevastopol agglomeration incorporates from 2 to 4 other municipalities. Kaliningrad Oblast has three delimitation options: firstly, the agglomeration is divided into industrial, coastal, and border zones (11 municipalities); secondly, into the agglomeration core and its satellites in the western part of the region based on their transport accessibility (13 municipalities); and thirdly, an approach incorporating major industrial cities, which is equal to almost the entire territory of the region. Krasnodar Krai has two delimitation options: based on transport accessibility, population, and industrial connections (11 municipalities) or an extended area to the north reaching Timashevsk (15 municipalities). Leningrad Oblast is generally regarded as part of Saint Petersburg agglomeration featuring three main approaches: municipalities adjacent to St. Petersburg (5 municipalities), includes settlements functionally gravitating to St. Petersburg, located in its zone of influence and having transport accessibility ( 8 municipalities) or an expanded territory to the north, including the entire southeastern part of the Vyborgsky district and the south of Priozerskiy district (8 municipalities). Murmansk Oblast has a unified approach to delimitation of its urban agglomeration incorporating 12 municipalities. Rostov Oblast has three main delimitation approaches: firstly, including the satellite cities of Rostov and adjacent municipalities, without Kagalnitsky and Oktyabrsky districts (11 municipalities); secondly, the agglomeration includes distant districts, 
including the cities of Shakhty and Novoshakhtinsk, as well as a suburban part of the Krasnosulinsky district (18 municipalities); thirdly, the greater area of Rostov agglomeration excluding Taganrog and the Neklinovsky district.

\section{RESEARCH RESULTS}

To better understand the digital capacity of tourist areas, we have carried out a comparative assessment of the development of the tourism sector in the regions under study. During 2005-2019, the total number of collective accommodation facilities for tourists in these regions increased 3 times and amounted to 9,865, and the number of people accommodated in them increased 2.5 times to 20.8 thousand people. The aggregate share of these regions has significantly increased relative to the general indicators for the country: in 2019 they accounted for $35 \%$ of all collective accommodation facilities (21.7\% in 2005) and 27.4\% of placed persons (in $2005-21.9 \%$ ). Leadership positions among the regions under consideration in terms of the number of tourist infrastructure are occupied by the Krasnodar region, the Republic of Crimea, and St. Petersburg. The same regions are also leading in the structure of Russian tourists sent on tours across the Russian Federation in 2019: Krasnodar region - 33.5\%, Republic of Crimea - 12\%, St. Petersburg - 6.8\%, and Leningrad Region - 2.6\%. According to the types of collective accommodation facilities in the regions of the sample in 2019, 26.6\% of hotels, $21 \%$ of hostels, $23.7 \%$ of sanatorium and resort organizations, and $24.8 \%$ of recreation organizations were concentrated from the total country volume. Table 2 shows the ranks of the studied tourist regions of Russia according to some significant indicators of the development of the tourist network.

Table 2. Ranks of some regions of Russia in terms of the development of the tourism sector (Source: calculated by the authors based on Rosstat data)

\begin{tabular}{|c|c|c|c|c|c|c|c|c|c|c|c|c|}
\hline \multirow[b]{3}{*}{ Region } & \multicolumn{4}{|c|}{ by the number of organizations } & \multicolumn{8}{|c|}{ by the number of people placed in } \\
\hline & \multirow[b]{2}{*}{$\begin{array}{l}\frac{n}{0} \\
\frac{0}{0}\end{array}$} & \multirow[b]{2}{*}{$\begin{array}{l}\frac{n}{0} \\
\stackrel{0}{0} \\
\stackrel{\Theta}{0}\end{array}$} & \multirow{2}{*}{ 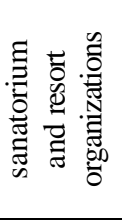 } & \multirow{2}{*}{ 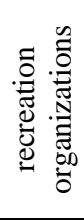 } & \multicolumn{2}{|c|}{ hotels } & \multirow{2}{*}{ 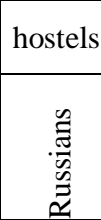 } & \multicolumn{3}{|c|}{$\begin{array}{c}\text { sanatorium and resort } \\
\text { organizations }\end{array}$} & \multicolumn{2}{|c|}{$\begin{array}{c}\text { recreation } \\
\text { organizations }\end{array}$} \\
\hline & & & & & 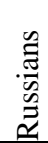 & 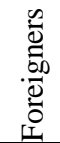 & & 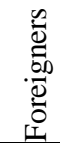 & 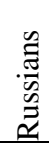 & 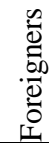 & 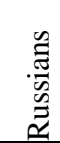 & 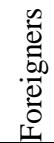 \\
\hline Krasnodar region & 1 & 2 & 1 & 1 & 1 & 2 & 2 & 4 & 1 & 1 & 1 & 3 \\
\hline St. Petersburg & 2 & 1 & 5 & 6 & 2 & 1 & 1 & 1 & 3 & 4 & 4 & 9 \\
\hline Republic of Crimea & 3 & 4 & 2 & 2 & 4 & 7 & 5 & 6 & 2 & 2 & 3 & 2 \\
\hline Rostov region & 4 & 3 & 4 & 4 & 3 & 5 & 3 & 2 & 5 & 7 & 5 & 6 \\
\hline Kaliningrad region & 5 & 5 & 6 & 9 & 6 & 4 & 6 & 3 & 4 & 5 & 9 & 7 \\
\hline Leningrad region & 6 & 8 & 3 & 3 & 5 & 3 & 4 & 8 & 6 & 9 & 2 & 1 \\
\hline Arkhangelsk region & 7 & 7 & 7 & 7 & 7 & 8 & 8 & 9 & 8 & 8 & 8 & 8 \\
\hline Murmansk region & 8 & 6 & 8 & 5 & 8 & 6 & 7 & 5 & 7 & 3 & 6 & 4 \\
\hline Sevastopol & 9 & 9 & 9 & 8 & 9 & 9 & 9 & 7 & 9 & 6 & 7 & 5 \\
\hline
\end{tabular}

Note: rank 1 means that the region occupies the best positions in the sample for the considered indicator

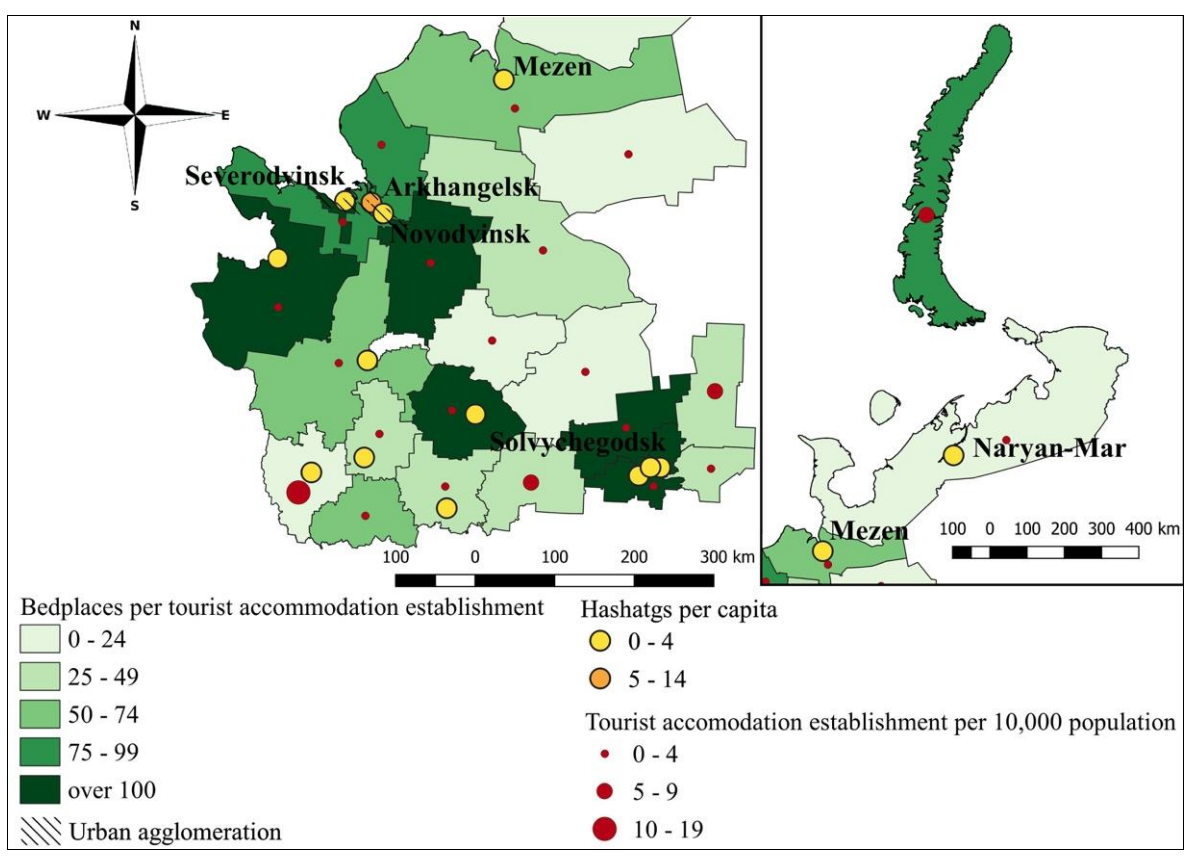

Figure 2. Digital capacity and tourist potential of the territory of the Arkhangelsk region, incl. Nenets Autonomous Okrug (Source: developed by the authors)
The analysis of the data presented in Table 2, on the one hand, demonstrates the superiority of the Krasnodar region in terms of tourist attractiveness among the studied regions of the Russian Federation, and on the other hand, demonstrates the differences between the regions in terms of the tourist flow. For example, among foreign tourists staying in hotels, the most popular destinations are St. Petersburg and the Leningrad region, focused on the development of cultural and historical tourism; Krasnodar region, where the mountain-ski resort of Sochi is located, which hosted the 2014 Olympics; and Kaliningrad region, which is a Russian exclave in the Baltic. A distribution for Russian tourists looks different - in the first places are the southern seaside resorts.

It is interesting that the northern regions (in particular the Murmansk

region) are chosen by foreign tourists for accommodation in sanatorium and resort organizations and recreation organizations, while from the side of Russian tourists this direction is less in demand. The analysis of this data helped us to better understand 
the relationship between the regions under study in terms of tourism specifics and the tourist flow to them, which was subsequently reflected in the volume of digital content generated. Figures 2-8 reflect the patterns of territorial distribution of digital content and tourist potential in the studied regions of the Russian Federation by municipalities. The northern regions -

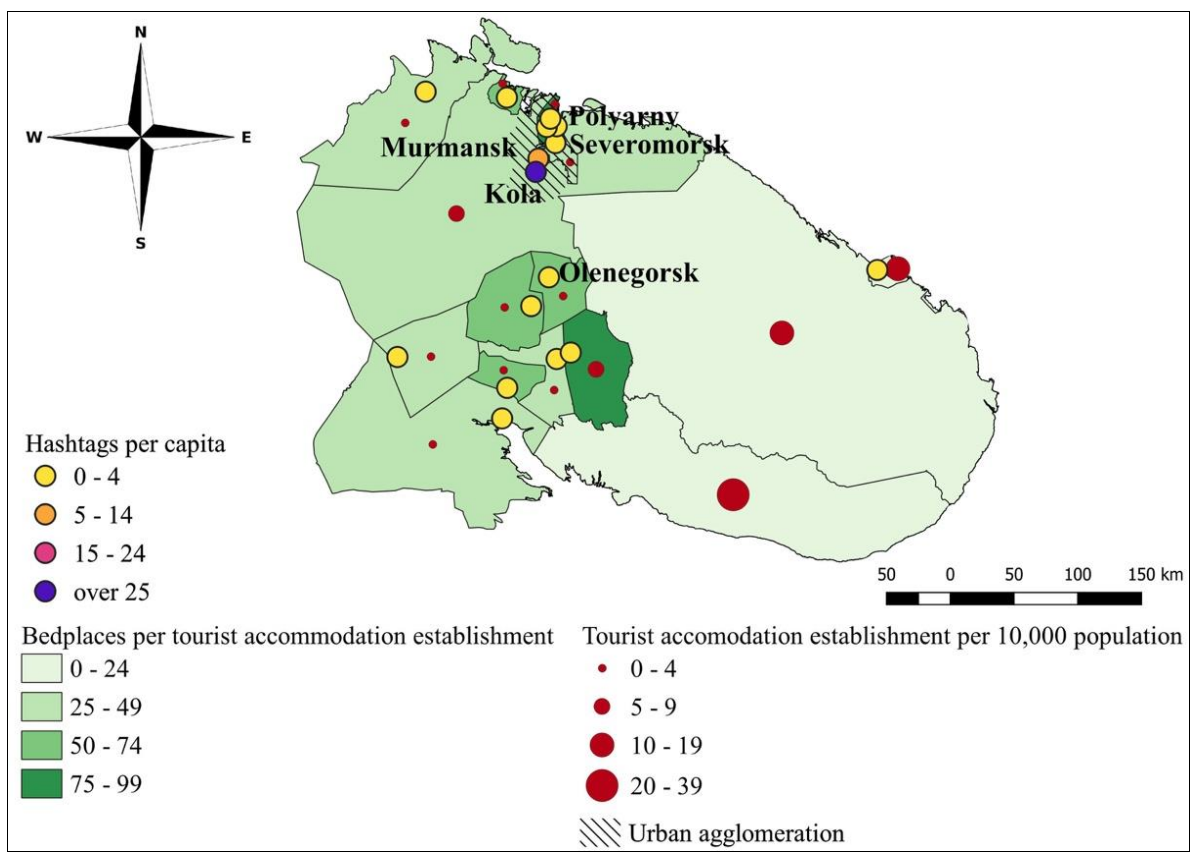

Figure 3. Digital capacity and tourist potential of the territory of the Murmansk region (Source: developed by the authors)
Arkhangelsk and Murmansk regions account for the smallest amount of digital content marked with hashtags (Table 1), which is natural due to the fact that these regions occupied one of the lowest positions in terms of tourist attractiveness among the studied regions in 2005-2019. At the same time, they have steady growth rates in the number of collective accommodation facilities and in the number of accommodation facilities in 2005-2019: 1.8 and 1.4 times for the Arkhangelsk region and 1.6 and 1.2 times for the Murmansk region. The largest amount of digital content is generated in urban agglomerations around the administrative-territorial centers of the regions - Figures 2, 3 . This is caused not only by the presence of tourist sites in them but also by the active entrepreneurial activity of local residents, which was revealed during a qualitative analysis of the generated content.

In the Arkhangelsk region, the largest concentration of digital content is in Arkhangelsk, which ranks 15 th among the cities in the sample in terms of the number of hashtags, and the nearby cities of Severodvinsk and Novodvinsk, which are part of the zone of its agglomeration influence. Outside the urban agglomeration, Solvychegodsk (3.7 hashtags per capita), which has been a member of the Association of the Most Beautiful Villages and Towns of Russia since 2020, and NaryanMar (3.4 hashtags per capita), where the Arctic Tourism Center is located with active, ecological, expeditionary, cultural tourism in unique natural places beyond the Arctic Circle are distinguished. The superposition of indicators on the development of tourism infrastructure on digital data also shows that these municipalities have relatively high indicators in terms of the number of accommodations per collective accommodation facility relative to the regional average - Figure 2 .

In the Murmansk region, the largest concentration of digital content is in Murmansk, which ranks 13th among the cities in the sample in terms of the number of hashtags, followed by the cities included in the zone of its agglomeration influence Kola, Severomorsk, Polyarny - Figure 3. By the relative number of hashtags per capita, the city of Kola stands out (31.8 hashtags per capita), which is the center of the Kola district. Despite the fact that a unique polar day festival is held annually in the city itself, most of the digital content is entrepreneurial in nature, due to the influence of the agglomeration factor. It should be noted that the Teriberka village is located on the territory of the Kola region, which was included in the top 20 best travel destinations by National Geographic Traveler magazine in 2016. The hashtag \#териберка is found at 126 thousand; it is also often used with \#кольскийполуостров (156 thousand) and \#мурманск (over 2.5 million). In terms of the absolute number of collective accommodation facilities for tourists, the Kola district takes 1st place in the region, and in terms of the number of places, it is second only to Murmansk. However, in relative terms per capita, the position of the municipality among other municipal districts of the region is more modest. Also, significant tourist sites in the Murmansk region (ski resorts, the Simbozersky reserve, the Oleniy Bereg agro-village, the Olenegorsky quarry, etc.) are located in the central part of the region near the cities of Kirovsk, Monchegorsk, Kandalaksha, Apatity, Olenegorsk - Figure 3. These cities account for $38 \%$ of the hashtags in the sample for the Murmansk region without the inclusion of \#мурманск, which is often referred to as related / duplicate. Also in the municipalities of these cities, $31.4 \%$ of all collective accommodation facilities for tourists in the region and $37.5 \%$ of places in them are located, and excluding Murmansk - 37 and $49 \%$.

The north-western tourist regions of Russia are represented in the study by three regions - St. Petersburg, the Leningrad region and the Kaliningrad region - Figures 4-5. As already noted, St. Petersburg is a large tourist center in Russia, attracting both Russian and foreign tourists. The number of collective accommodation facilities for tourists in it for 2005-2019 increased 7 times to 1,000, and the number of people placed - 3 times (over 6 million people in 2019). The largest share of Russian tourists visiting St. Petersburg is occupied by residents of Moscow and the Moscow region, as well as the Republic of Tatarstan. A vast agglomeration zone has formed around St. Petersburg, which includes most cities with high relative indicators of the number of hashtags per capita; the largest number of attractions is also located here - Figure 4. It is especially worth noting a number of tourist-significant cities that are part of the intracity municipalities subordinate to St. Petersburg, and have the high digital capacity - these are Peterhof (11.05 hashtags per capita), Kronstadt (8.85 hashtags per capita), Sestroretsk (5.74 hashtags per capita) and Zelenogorsk (5.02 hashtags per capita). Also, in terms of the absolute number of hashtags among the cities of the 
Leningrad region, Vyborg, Gatchina, Kudrovo, Otradnoye, Sosnovy Bor, Murino stand out, which are included in the zone of agglomeration influence of St. Petersburg, accumulating a significant number of attractions (https://www.lentravel.ru). The

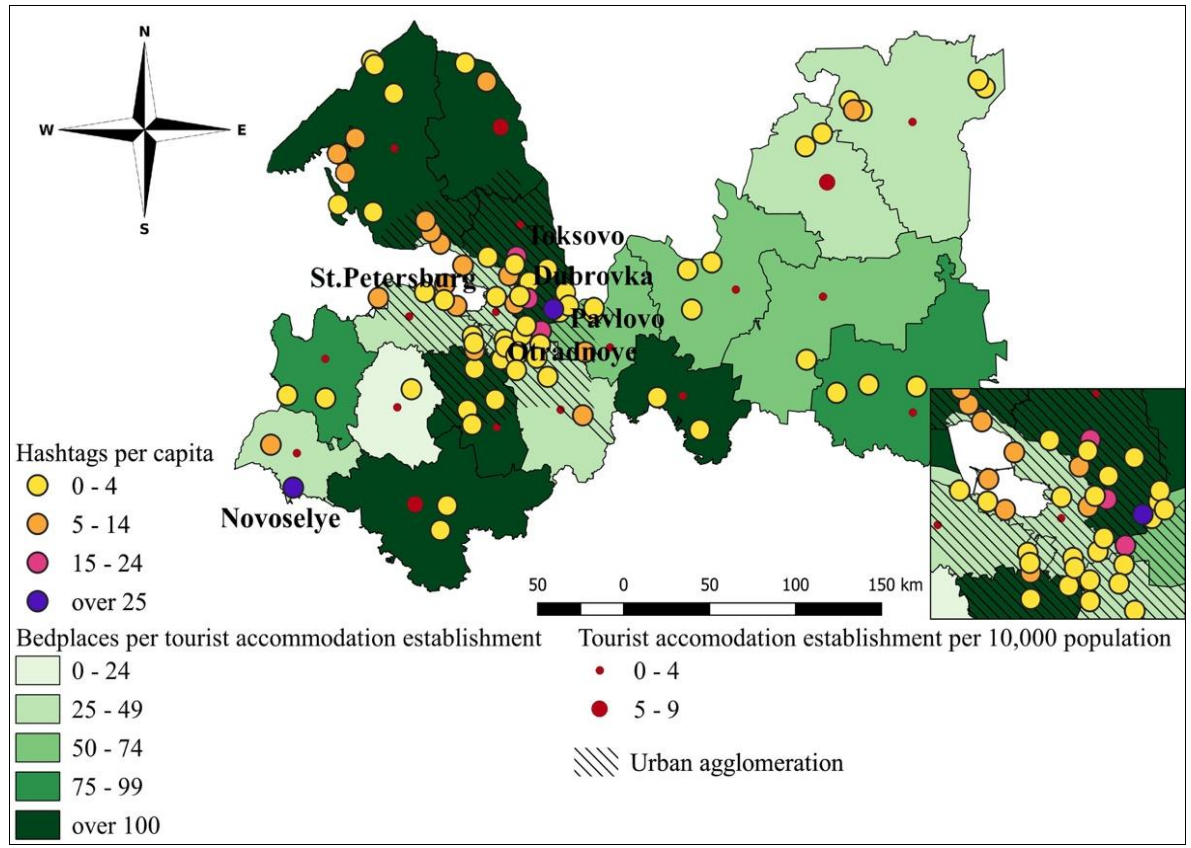

Figure 4. Digital capacity and tourist potential of the territory

of the Leningrad region and St. Petersburg (Source: developed by the authors)

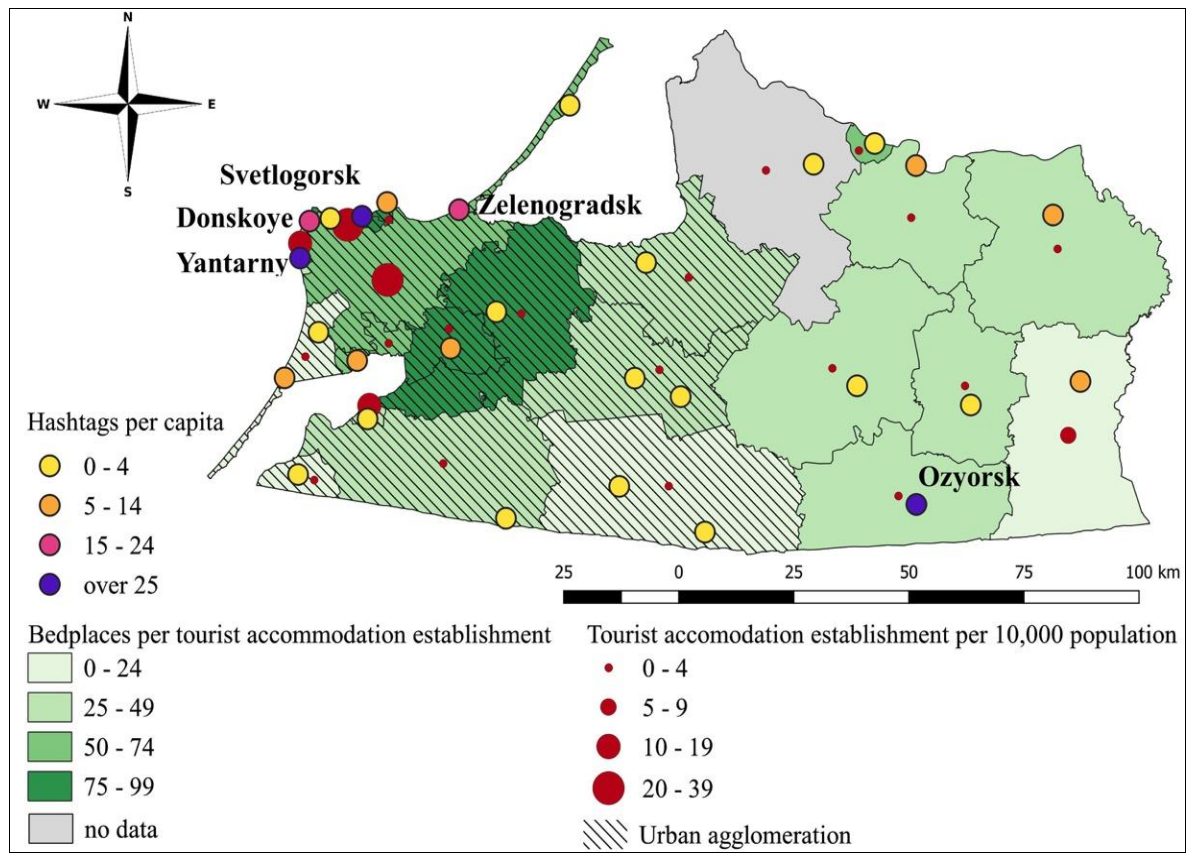

Figure 5. Digital capacity and tourist potential of the territory of the Kaliningrad region (Source: developed by the authors)
Kaliningrad region is an actively developing tourist region of Russia, attracting not only domestic tourists (mainly from Moscow, the Moscow region, St. Petersburg, as well as the northern regions of the country) but also a significant number of foreigners (Table 2). In 2020, the region was ranked in the Top 25 trending destinations in the World by TripAdvisor's Travelers' Choice Awards. In terms of the total number of hashtags of city names among the regions of the sample, the Kaliningrad region took 5 th place. The 5th place is also held by the administrative-territorial center of the region - the city of Kaliningrad, which, in terms of the number of personal hashtags (almost 7 million), was only behind the Krasnodar, Sochi, St. Petersburg, Rostov-on-Don. Two more resort cities of the region (Svetlogorsk, Zelenogradsk) entered the top 50 among 205 surveyed cities in terms of the absolute number of hashtags. In general, the territorial distribution of the indicators of the digital capacity of the cities of the Kaliningrad region corresponds to the distribution of the tourist infrastructure along the resort sea coast of the Baltic Sea - Figure 5 .

Southern regions are most numerous among the considered group of tourist regions of Russia, which includes the Krasnodar region, Rostov Region, the Republic of Crimea and Sevastopol - Figures 6-8. The cities of these regions are strong attractors of tourists, primarily residents of other regions of Russia. Leadership is by the Krasnodar region with over 8 million people accommodated in the collective accommodation facilities in 2019, which is 3 times more than in 2005. The main flow of tourists

from Moscow, the neighboring Rostov region, the Republic of Tatarstan, as well as Sverdlovsk, Yaroslavl, Moscow, Tyumen, Nizhny Novgorod regions, Perm region, and St. Petersburg. The main tourist infrastructure of the Krasnodar region is concentrated in municipalities along the coastline, primarily in the urban districts of Sochi, Anapa, Gelendzhik, and Tuapse districts. Cities in these municipalities were also the leaders in personal hashtags both within the region and among all cities in the sample: Anapa - 61.8, Gelendzhik - 51.7, Sochi - 49.3, Tuapse - 18.6 hashtags per capita. Interestingly, the administrativeterritorial center of Krasnodar took only 4th place in terms of digital capacity (32 hashtags per capita) among the cities of the region and its agglomeration influence in relation to the generation of digital content was significantly less noticeable than in other regions of the sample - Figure 6. In second place in terms of tourist attractiveness among the southern regions of the European part of Russia and in 3rd place among the regions of the sample - the Republic of Crimea and Sevastopol, which, being located on the Crimean peninsula, are, in fact, a Russian quasi-exclave (transport communication with the main part of the country is carried out through the Kerch bridge). In Crimea (the Republic of Crimea and Sevastopol) in 2019, there were about 1.5 thousand 
collective accommodation facilities. Their number increased by $9 \%$ compared to 2015 , while the volume of the tourist flow - by $36 \%$ (more than 2.6 million tourists were accommodated in 2019). The main tourist infrastructure of Crimea is located

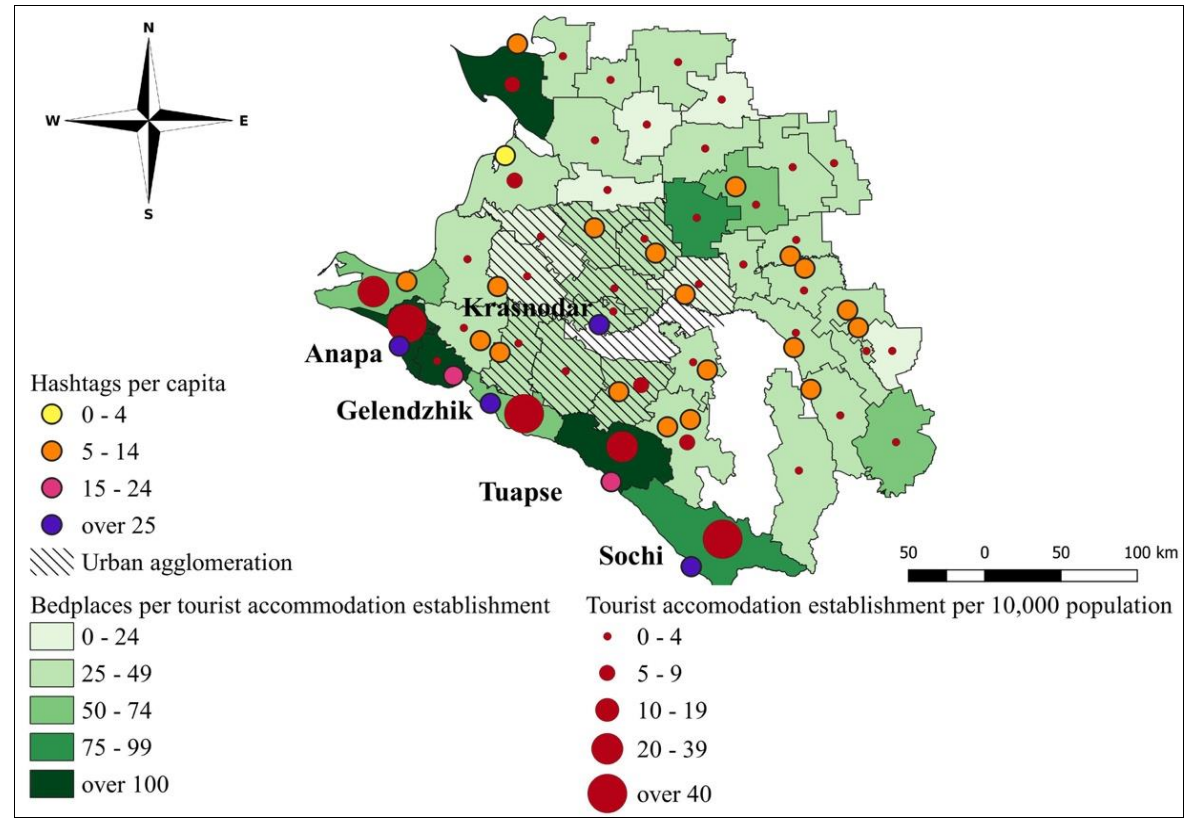

Figure 6. Digital capacity and tourist potential of the Krasnodar region (Source: developed by the authors)

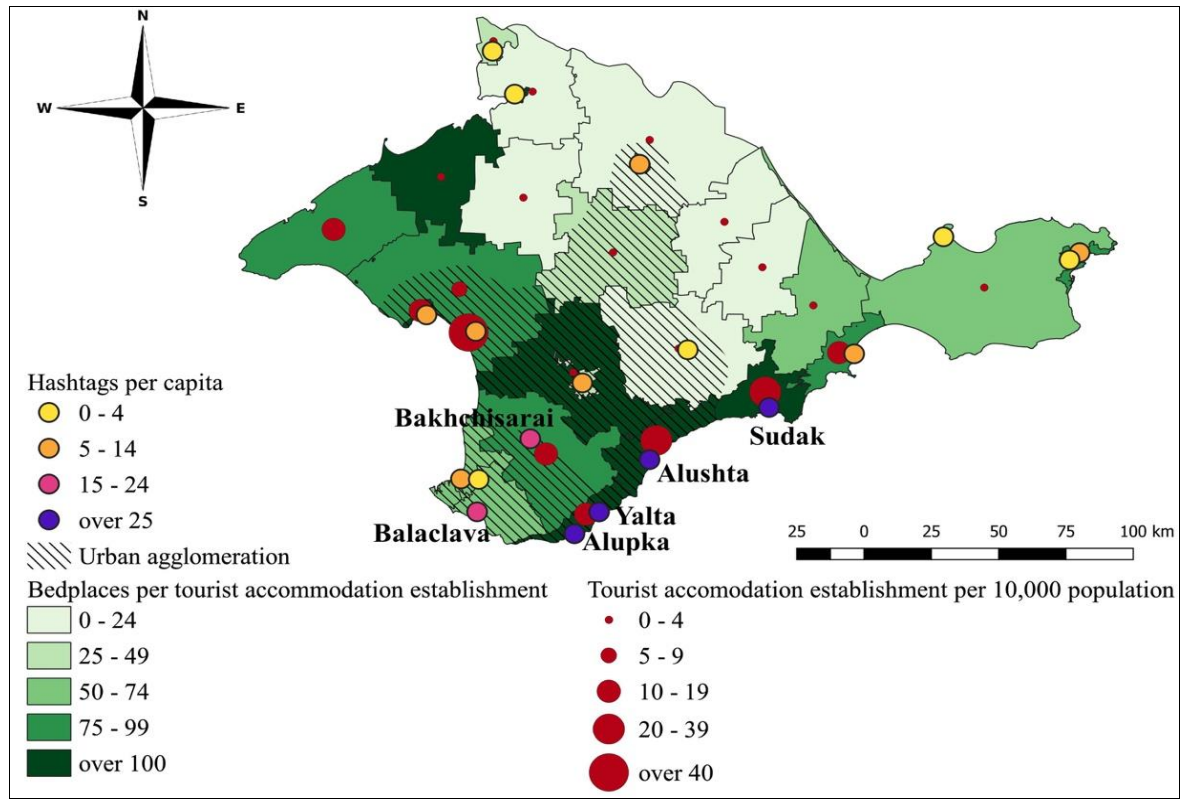

Figure 7. Digital capacity and tourist potential of the territory of the Republic of Crimea and Sevastopol (Source: developed by the authors) on the Black Sea coast in the urban districts of Saki, Yalta, Alushta, Evpatoria, Feodosia, Sudak, Bakhchisaray municipal districts and Balaklava municipal district, which is the inner city of Sevastopol - Figure 7. Despite the fact that most of the territories of these municipalities are located in the zone of agglomeration influence of the administrative centers of Simferopol and Sevastopol, in relation to their digital capacity the factor of tourist attractiveness plays a greater role. This is confirmed by the superiority of the coastal tourist cities over Simferopol (10.1) and Sevastopol (9.9) in terms of the number of personal hashtags per capita: Sudak 58.2, Yalta - 42.8, Alupka - 31.9, Alushta - 30.7, Balaklava - 21.1, Bakhchisarai - 15.4, Feodosia - 12.5, Evpatoria - 11.9, and Saki - 11.15.

An interesting example is the Rostov region, the collective accommodation facilities of which served 1.3 million people in 2019. In 2005-2019 the region showed an increase in accommodation facilities and the number of tourists by 2.3 times. When placing tourist infrastructure, a strong influence of the agglomeration factor is observed: the majority of collective accommodation facilities for tourists are concentrated in Rostov-on-Don and in neighboring Taganrog and Aksakai districts, as well as in a large city Volgodonsk in the east of the region where the nuclear power plant is located - Figure 8. The distribution of toponymic hashtags of cities follows the contours of the metropolitan agglomeration, most of them are in Rostov-on-Don (about 10 million) and on average, from 1 to 2 Million in Taganrog, Novocherkassk, Bataysk, Shakhty, Azov, Aksai. Volgodons and Donetsk are also visible on the digital map (however, the latter does not have a unique topographic name and some of the hashtags may belong to other settlements). In relative terms, Rostov-onDon (8.5) and the closest to it Aksai (18.9), Azov (11), Bataysk (8.2) are in the lead but a qualitative analysis of digital content indicates the superiority of personal and business content over tourist content.

\section{CONCLUSIONS}

Digitalization of industries and society is the contemporary trend taking place all around the globe. Russia is one of the countries with strong integration of information and communication technologies (ICT) into the everyday life of the population. Russia holds 5th place by mobile cellular subscriptions with $83 \%$ of the population being subscribed to the mobile networks (ITU, 2020) and 6th place by the number of Internet users (CIA, 2019). According to the GSMA Mobile Connectivity Index (2019), Russia ranks 24th by consumer readiness (scoring 88.5 out of 100) and 39th overall, having 95\% of the population covered by the $3 \mathrm{G}$ network. Citizens are increasingly adopting digital technologies in their daily routines becoming increasingly experienced users. This trend is supported by the government with numerous national programs and 


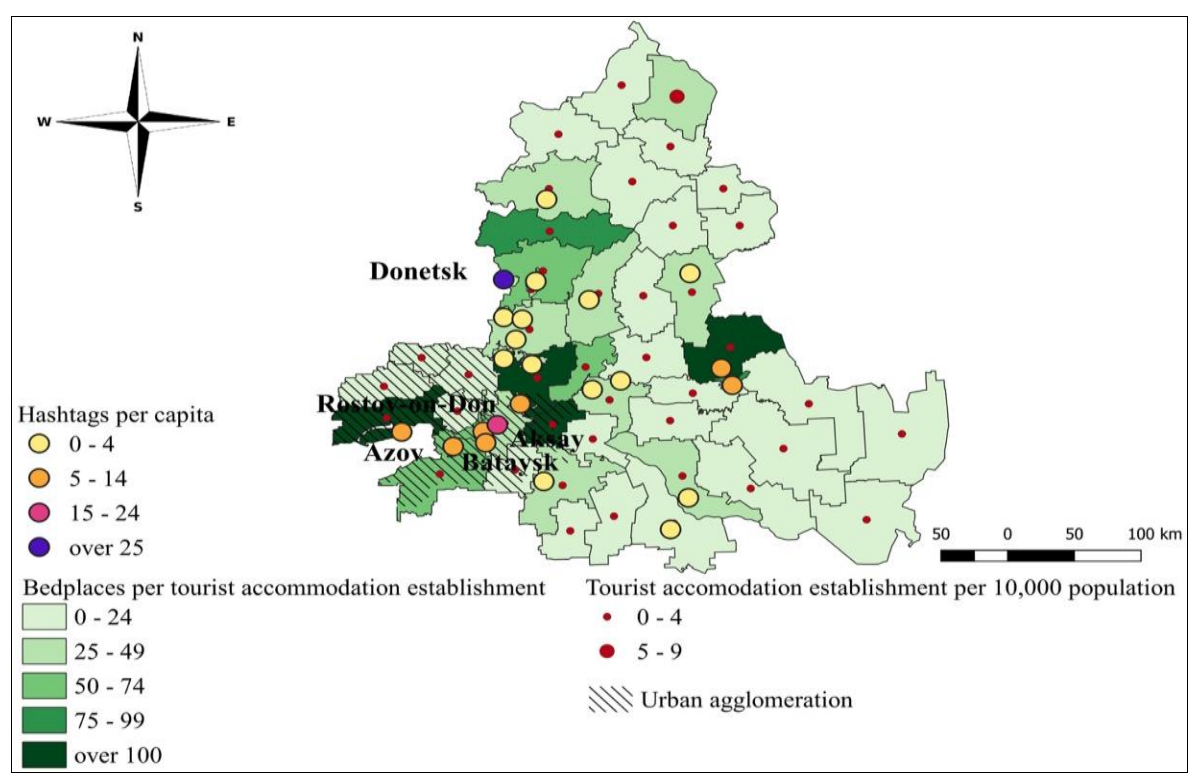

Figure 8. Digital capacity and tourist potential of the territory

of the Rostov region (Source: developed by the authors) strategic documents aimed at intensification of modern digital technologies being used by government organizations, businesses, and citizens: the State Program "Information Society (2011-2020)", "Strategy of Innovative Development of the Russian Federation until 2020 (Government Decree No. 2227-R of 2011)", "The strategy for the development of the information technology industry in the Russian Federation for 2014-2020 and for the future until 2025", "Strategy for Scientific and Technological Development of the Russian Federation", "Development of the Information Technology Industry" roadmap, the program "Digital Economy of the Russian Federation", "Information Society Development Strategy in the Russian Federation for 2017-2030". Studies indicate that Russia is steadily moving towards a 'digital society' with modern digital technologies being well adopted by the population in online shopping, electronic banking, and utilities, as well as a variety of services dominated by recreation (Levashov and Grebnyak, 2020; Popov and Semyachkov, 2018). The study develops on the digital capacity of territories defines as the ability of territories to generate digital content. The focus of the article was the customer-generated content (CGC) related to the tourism industry - one of the information-intensive and rapidly digitalizing economy sectors worldwide. With the development of Web 2.0 and social media, users are increasingly relying on the digital content of other users, which is preferred to purely commercial information. Various tourist experiences, feedback, observations, comments, stories, and most importantly the media content - videos and photos, are becoming the primary source of information on travel destinations. It is expected that popular tourist destinations and major tourist sites have the capacity to generate the highest volume of CGC as travelers are willing to memorize their experience, acknowledge the fact of 'being there', and share their emotions with friends.

We, therefore, set the hypothesis that the new types of digital data (big data) can act as a marker of the tourism industry development potential. Our research design is based on using the place-related hashtags in Instagram for tracking the distribution of tourism-related CGC. This social media is highly popular around the globe and was found equally representative in the regions under consideration. Across the 205 urban settlements studied located in 10 regions of Russia - Arkhangelsk region (including the Nenets Autonomous District), Murmansk region, Leningrad region, St. Petersburg, Kaliningrad region, Krasnodar region, Rostov region, Republic of Crimea, and Sevastopol, the total of 161.4 million hashtags were analyzed dominated by St. Petersburg and the southern resorts of Krasnodar region, Rostov region, and the Republic of Crimea. These findings are fully in line with the distribution of collective accommodation facilities and patterns of tourist flows. By considering the regional level data we confirm the hypothesis set - the regions with highly developed tourist industry tend to excel in user-generated content in social media.

However, there are certain methodological aspects that could act as a research limitation as to the municipal level. The limitations of using CGC in measuring the tourism industry development are generally related to the ambiguity of metadata set by the users. The following generalized examples are distinguished. Firstly, users tend to indicate a location-specific hashtag of a large city, usually an administrative center of the region, in addition, or instead of the name of a particular municipality they are actually describing. This is often the case when the location is less known, and the readers will have difficulties in understanding the context. Moreover, the hashtags of unpopular locations will generate fewer views, thus, stimulating users to indicate more popular destinations nearby. Due to this reason larger cities and the regional administrative centers receive additional mentions, which artificially boosts their digital capacity while decreasing the performance of less-known destinations, or resulting in a double count. Secondly, some toponyms are identical to words describing certain irrelevant objects - coast, amber, sun, soviet, peace, or even names (e.g. Pushkin), which distorts the results from using hashtags in defining the location. Our experience suggests that an additional word, such as 'city' or similar, should be applied for data validation. Thirdly, the agglomeration factor introduces a strong distortion, since a lot of content is entrepreneurial in nature. When deep-diving into the content identified, we have found that large cities tend to feature non-related commercial content of various small businesses and self-employed - hairdressers, beauty services, craft shops, photo studios, cafes, and shops, etc. Tourist-like content is also registered in northern regions of Russia uploaded by people employed in rotational work.

\section{Acknowledgments}

The study was funded by RFBR according to the research project No. 20-011-32062 "Regions of Russia towards a digital nation: spatial divergence in virtualization of socio-political and economic relations". A.A. Mikhaylova expresses her gratitude to the 5-100 competitiveness program of the Immanuel Kant Baltic Federal University for supporting her research fellowship. A.S. Mikhaylov acknowledges the support of the IG RAS project No. 0148-2019-0008, AAAA-A19-119022190170-1 "Problems and prospects of Russia's territorial development in the context of its unevenness and global instability". 


\section{REFERENCES}

Abou-Shouk, M., Lim, W.M., \& Megicks, P. (2013). Internet adoption by travel agents: a case of Egypt. International Journal of Tourism Research, 15(3), 298-312.

Aramendia-Muneta, M.E., Olarte-Pascual, C., \& Ollo-López, A. (2021). Key Image Attributes to Elicit Likes and Comments on Instagram. Journal of Promotion Management, 27(1), 50-76. https://doi.org/10.1080/10496491.2020.1809594

Blackshaw, P., \& Nazzaro, M. (2006). Consumer-Generated Media (CGM) 101: Word-of-mouth in the age of the Web-fortified consumer. Retrieved. NewYork: Nielsen Buzz Metrics. URL. https://www.yumpu.com/en/document/read/6837546/consumer-generated-media-cgm-101-nielsen-online

Bouzguenda, I., Alalouch, C., \& Fava, N. (2019). Towards Smart Sustainable Cities: A Review of the Role Digital Citizen Participation

Brodovskaya, E.V., \& Huang, T. (2019). Digital generation: Civil mobilization and political protest among russian youth. Monitoring Obshchestvennogo Mneniya: Ekonomicheskie i Sotsial'Nye Peremeny, 153(5), 3-18. https://doi.org/10.14515/monitoring.2019.5.01

Choe, Y., Kim, J., \& Fesenmaier, D.R. (2017). Use of social media across the trip experience: An application of latent transition analysis. Journal of Travel \& Tourism Marketing, 34(4), 431-443. https://doi.org/10.1080/10548408.2016.1182459

García-Palomares, J.C., Gutiérrez, J., \& Minguez, C. (2015). Identification of tourist hot spots based on social networks: A comparative analysis of European metropolises using photo-sharing services and GIS. Applied Geography, 63, 408-417. https://doi.org/10.1016/j.apgeog.2015.08.002

Girardin, F., Blat, J., Calabrese, F., Dal Fiore, F., \& Ratti, C. (2008). Digital footprinting: Uncovering tourists with user-generated content. IEEE Pervasive Computing, 7 (4), 4653470, 36-44. https://doi.org/10.1109/MPRV.2008.71

Gunter, U., \& Önder, I. (2021). An Exploratory Analysis of Geotagged Photos From Instagram for Residents of and Visitors to Vienna Journal of Hospitality and Tourism Research, 45(2), 373-398. https://doi.org/10.1177/1096348020963689

Happ, E., \& Horváth Ivancsóné, Z. (2020). A study of digital marketing tools usage habits among Hungarian tourists. GeoJournal of Tourism and Geosites, 32(4), 1283-1289. https://doi.org/10.30892/gtg.32414-570

Hu, G., Chohan, S.R., \& Liu, J. (2020). Does IoT service orchestration in public services enrich the citizens' perceived value of digital society? Asian Journal of Technology Innovation, Article in press. https://doi.org/10.1080/19761597.2020.1865824

Jiang, K., Yin, H., Wang, P., \& Yu, N. (2013). Learning from contextual information of geo-tagged web photos to rank personalized tourism attractions. Neurocomputing, 119, 17-25. https://doi.org/10.1016/j.neucom.2012.02.049

Kadar, B., \& Gede, M. (2013). Where do tourists go? Visualizing and analysing the spatial distribution of geotagged photography. Cartographica, 48 (2), 78-88. https://doi.org/10.3138/carto.48.2.1839

Kuznetsov, S.V., Lachininskiy, S.S., Mikhaylov, A.S., \& Shendrik, A.V. (2019). "Propulsive industries" of the regions of russia's western borderland under of geopolitical turbulence. Economy of Region, 15(4), 1253-1265. https://doi.org/10.17059/2019-4-22

Leung, D., Law, R., van Hoof, H., \& Buhalis, D. (2013). Social Media in Tourism and Hospitality: A Literature Review. Journal of Travel \& Tourism Marketing, 30(1-2), 3-22. https://doi.org/10.1080/10548408.2013.750919

Levashov, V.K., \& Grebnyak, O.V. (2020). Digital culture of the Russian society and the state. Sotsiologicheskie Issledovaniya, 2020(5), 7989. https://doi.org/10.31857/S013216250009401-4

Li, J., Xu, L., Tang, L., Wang, S., \& Li, L. (2018). Big data in tourism research: A literature review. Tourism Management, 68, $301-323$. https://doi.org/10.1016/j.tourman.2018.03.009

Li, X., Law, R., Xie, G., \& Wang, S. (2021). Review of tourism forecasting research with internet data. Tourism Management, 83, 104245. https://doi.org/10.1016/j.tourman.2020.104245

Ma, Y., Xiang, Z., Du, Q., \& Fan, W. (2018). Effects of user-provided photos on hotel review helpfulness: An analytical approach with deep leaning. International Journal of Hospitality Management, 71, 120-131. https://doi.org/10.1016/j.ijhm.2017.12.008

Mikhaylova, A.A. (2019). The role of innovations in providing economic security: The Estonian case. Sovremennaya Evropa, $7,136-147$. https://doi.org/10.15211/SOVEUROPE72019136147

Munar, A. M., \& Jacobsen, J.K.S. (2014). Motivations for sharing tourism experiences through social media. Tourism Management, 43, 4654. https://doi.org/10.1016/j.tourman.2014.01.012

Önder, I., Koerbitz, W., \& Hubmann-Haidvogel, A. (2016). Tracing tourists by their digital footprints: The case of Austria. Journal of Travel Research, 55 (5), 566-573. https://doi.org/10.1177/0047287514563985

Orsi, F., \& Geneletti, D. (2013). Using geotagged photographs and GIS analysis to estimate visitor flows in natural areas. Journal for Nature Conservation, 21 (5), 359-368. https://doi.org/10.1016/j.jnc.2013.03.001

Payntar, N.D., Hsiao, W.L., Covey, R.A., \& Grauman, K. (2021). Learning patterns of tourist movement and photography from geotagged photos at archaeological heritage sites in Cuzco, Peru. Tourism Management, 82, 104165. https://doi.org/10.1016/j.tourman.2020.104165

Pencarelli, T. (2020). The digital revolution in the travel and tourism industry. Information Technology and Tourism, 22(3), 455-476. https://doi.org/10.1007/s40558-019-00160-3

Popov, E.V., \& Semyachkov, K.A. (2018). Problems of economic security for digital society in the context of globalization. Economy of Region, 14(4), 1088-1101. https://doi.org/10.17059/2018-4-3

Ruiz-Gómez, L.M., Navío-Marco, J., \& Rodríguez-Hevía, L.F. (2018). Dynamics of digital tourism's consumers in the EU. Information Technology and Tourism, 20(1-4), 59-81. https://doi.org/10.1007/s40558-018-0124-9

Schou, J., \& Hjelholt, M. (2018). Digital citizenship and neoliberalization: governing digital citizens in Denmark. Citizenship Studies, 22(5), 507-522. https://doi.org/10.1080/13621025.2018.1477920

Stankov, U., \& Gretzel, U. (2020). Tourism 4.0 technologies and tourist experiences: A human-centered design perspective. Information Technology and Tourism, 22(3), 477-488. https://doi.org/10.1007/s40558-020-00186-y

Tupay, P.K. (2020). Estonia, the digital nation: Reflections on a digital citizen's rights in the european union. European Data Protection Law Review, 6(2), 294-300. https://doi.org/10.21552/edpl/2020/2/16

Vu, H.Q., Li, G., Law, R., \& Ye, B.H. (2015). Exploring the travel behaviors of inbound tourists to Hong Kong using geotagged photos. Tourism Management, 46, 222-232. https://doi.org/10.1016/j.tourman.2014.07.003

Xiang, Z., \& Gretzel, U. (2010). Role of social media in online travel information search. Tourism Management, 31(2), 179-188. https://doi.org/10.1016/j.tourman.2009.02.016

Yeoman, I., \& McMahon-Beattie, U. (2006). Tomorrow's tourist and the information society. Journal of Vacation Marketing, 12(3), 269291. https://doi.org/10.1177/1356766706064623

Yuan, Y., \& Medel, M. (2016). Characterizing international travel behavior from geotagged photos: A case study of Flickr. PLoS ONE, 11 (5), e0154885. https://doi.org/10.1371/journal.pone.0154885

*** Could Play in Advancing Social Sustainability. Sustainable Cities and Society, 101627. https://doi.org/10.1016/j.scs.2019.101627

*** GSM Association (2019). The state of mobile internet connectivity 2019. URL. https://www.gsma.com/mobilefordevelopment

*** GSMA Mobile Connectivity Index (2019). URL: https://www.mobileconnectivityindex.com/\#year=2019\&zoneIsocode=RUS

*** International Telecommunication Union (2020). Measuring digital development Facts and figures 2020. URL. https://www.itu.int/ en/ITU-D/Statistics/Pages/facts/default.aspx

*** Miniwatts Marketing Group (2021). Internet usage statistics. The Internet big picture. URL. https://www.internetworldstats.com/stats.htm

*** U.S. Central intelligence agency (2019). The world factbook: Internet users, 2019. URL. https://www.cia.gov/the-worldfactbook/countries/world/\#communications

*** World Bank (2021). Individuals using the Internet. URL. https://data.worldbank.org/indicator/IT.NET.USER.ZS?end=2019\&start=2000

*** World Bank International Telecommunication Union (ITU). URL. https://data. worldbank.org/indicator/IT.NET.USER.ZS?end=2019\&start=2000

Article history: Received: 14.01.2021 Revised: 26.02.2021 Accepted: 01.04.2021 Available online: 26.04.2021 